\title{
Analysis of Genetic Diversity of Chukar Partridge (Alectoris chukar) Populations in Khorasan-e-Razavi Province of Iran by RAPD-PCR
}

\author{
Hassan Abbasi • Mojtaba Tahmoorespour • \\ Mohammad R. Nassiri · Shahrokh Ghovvati
}

Received: 8 November 2009/Accepted: 29 July 2010/Published online: 5 September 2010

(C) Springer Science+Business Media, LLC 2010

\begin{abstract}
RAPD markers were used to investigate population genetic parameters of an endangered partridge, Alectoris chukar, in four areas of Iran, as a part of a genetic conservation program. The aim of this study was to analyze the genetic similarity among these populations. Blood samples from 75 birds were used for DNA extraction and RAPD-PCR analysis of 67 loci, with 28 polymorphic bands $(41.79 \%)$. The populations of Kalat-e-Nader and Mashhad were found to be closely related, as were the Torbat-e-Jaam and the Quchan populations. Mean heterozygosity for all populations was $0.4405 \pm 0.0755$. The results indicate that chukar partridge genetic diversity in Khorasan-e-Razavi province is sufficient and the amount of gene flow among populations is acceptable.
\end{abstract}

Keywords Chukar partridge - Genetic diversity - RAPD-PCR (random amplified polymorphic DNA-polymerase chain reaction) · Khorasan-e-Razavi province . Gene flow

\section{Introduction}

The partridge commonly referred to as chukar (Alectoris chukar, Galliformes) is one of the most common and popular game birds in Khorasan-e-Razavi province, of northeastern Iran. Wild populations of this partridge have decreased dramatically because of destruction of their habitat, excessive hunting, migration, and other factors, causing them to be placed on lists of conservation concern in recent years. This most widespread species of partridge is distributed from the Balkans to the eastern Mediterranean islands and across Asia Minor to the Himalayas, Mongolia, and China. Moreover, this species has been successfully introduced into the western

H. Abbasi · M. Tahmoorespour · M. R. Nassiri · S. Ghovvati ( $\square)$

Ferdowsi University of Mashhad, P.O. Box 91775-1163, Mashhad, Iran

e-mail: Ghovvati@stu-mail.um.ac.ir 
USA, Canada, and New Zealand (Madge and McGowan 2002). Little is known about the genetic structure of the chukar. The lack of information is potentially harmful for its conservation (Frankham 2005).

Conservation attempts have been limited; management practices are based almost solely on controlled burning, leaving areas of varying post-fire age to maintain optimal habitat availability (McFarland 1991). The analysis of genetic variability is an essential ingredient for conservation programs, and the approach must be based on a combination of phenotypic and genetic data (Hetzel and Drinkwater 1992). The use of molecular markers can aid in the choice of breeds and populations to be conserved, when there is a shortage of resources, as well as the estimation of genetic variability of species breeds and populations (Egito et al. 2005). Random amplified polymorphic DNA (RAPD) is a useful approach to assessing genetic variation for conservation of wild populations; it is based on PCR amplification of genomic DNA with arbitrary nucleotide sequence primers. The RAPD marker can detect high levels of DNA polymorphism and can produce fine genetic markers (Williams et al. 1990; Welsh and McClelland 1990). This method is simple and quick to perform when there is no prior knowledge about the genetic make-up of the organism (Hadrys et al. 1992). Nevertheless, RAPD analysis has some limitations. It shows dominant inheritance, and marker/marker homozygotes cannot be distinguished from marker/null heterozygotes (Williams et al. 1990). This peculiarity of RAPDs impedes direct estimations of allele frequency and can bias calculations of population differentiation (Lynch and Milligan 1994). This problem can be overcome by appropriate statistical methods, such as analysis of molecular variance, AMOVA (Excoffier et al. 1992), which is not influenced by the dominance problem (Huff et al. 1993; Diaz et al. 2001). In addition, it is unable to assign bands to specific loci unless a previous pedigree analysis is performed. In applying this method, it is assumed that populations are in Hardy-Weinberg equilibrium, that polymorphic bands segregate in the Mendelian way, and that marker alleles from different loci do not comigrate to the same position in the gel (D'Amato and Corach 1996). The problem of low reproducibility in early RAPD analyses can now be overcome through improved laboratory techniques and band scoring procedures (Nybom 2004; Volis et al. 2001). RAPD markers, despite their limitations, provide a useful approach for evaluating a population's genetic differentiation, particularly in species that are poorly known genetically (Nybom 2004).

The aim of this study was to investigate the genetic diversity of the chukar partridge in four areas of Khorasan-e-Razavi province of Iran, as a part of a genetic conservation program.

\section{Materials and Methods}

\section{Study Area}

Khorasan-e-Razavi province, in northeastern Iran, has an area of $118,854 \mathrm{~km}^{2}$, including many areas such as Kalat-e-Nader, Mashhad, Shirvan, Torbat-e-Jaam, and Quchan (Fig. 1a). The climate is typically characterized by cold rainy winters and 

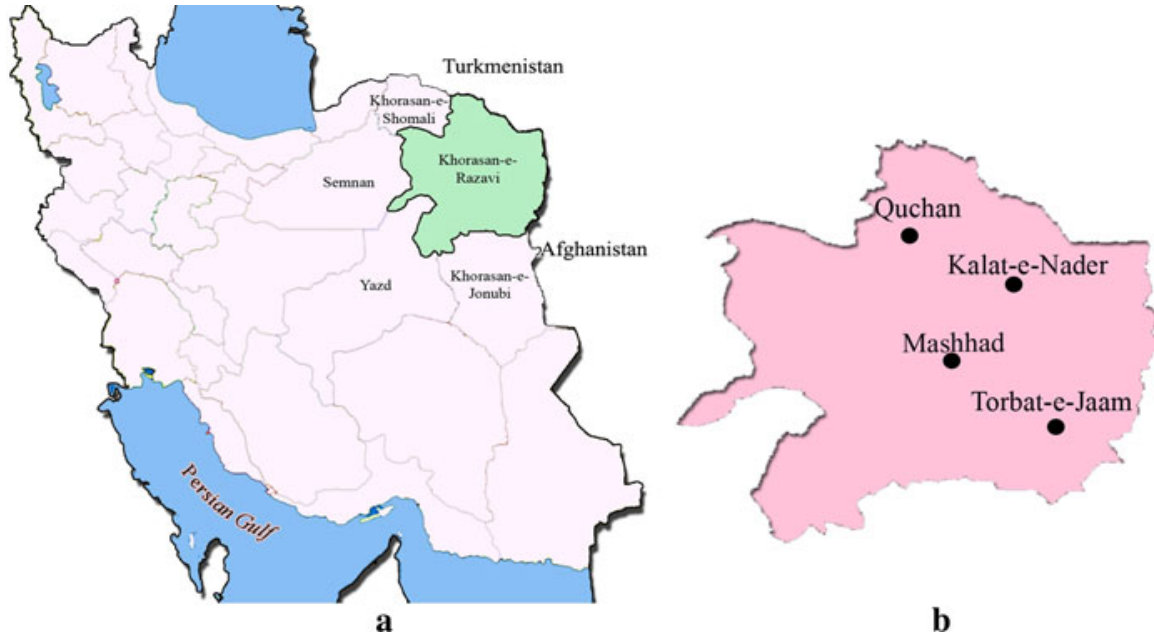

Fig. 1 The study area: a Location of Khorasan-e-Razavi province within Iran. b Sampling locations in Khorasan-e-Razavi province

relatively hot summers, depending on Siberian and Mediterranean high-pressure circulations. The average annual rainfall is around $200 \mathrm{~mm}$. According to rainfall records, a year can be divided into a dry season (summer and autumn) and a wet season (winter and spring) with about $75 \%$ of the total rainfall.

\section{Sample Collection and DNA Extraction}

Blood samples were collected from 75 chukar in four areas: Kalat-e-Nader (19 samples), Mashhad (21), Torbat-e-Jaam (18), and Quchan (17) (Fig. 1b). Individual blood samples $(1 \mathrm{ml})$ were taken from the brachial vein under the wing using disposable syringes and transferred immediately into tubes containing 15\% EDTA as an anticoagulant agent. Total genomic DNA was extracted from blood using the guanidinium isothiocyanate-silica gel method described by Boom et al. (1990), with minor modification. The total DNA concentration and its purity were measured with a Nano-Drope ND-2000 spectrophotometer (Thermo, Wilmington, USA), the DNA was diluted to a final concentration of $50 \mathrm{ng} / \mu \mathrm{l}$ in $\mathrm{dH}_{2} \mathrm{O}$ and stored at $4{ }^{\circ} \mathrm{C}$.

PCR and Data Analysis

Amplifications for RAPD markers were performed according to Negro et al. (2001) and Barbanera et al. (2005). The reaction mixture contained $20 \mathrm{ng}$ template DNA, $25 \mathrm{pM}$ (PH primers) or $18.75 \mathrm{pM}$ (OP primers) of a single decanucleotide (Table 1), $0.2 \mathrm{mM}$ each of dNTPs (Pharmacia, Uppsala, Sweden), $3 \mathrm{mM} \mathrm{MgCl}$, and $1 \mathrm{U} \mathrm{Taq}$ polymerase (Invitrogen, USA) in the reaction buffer provided by the manufacturer; sterile distilled water was added for a final volume of $20 \mu \mathrm{l}$. Amplification was performed in an ABI 9700 thermal cycler (Applied Biosystems, Calif., USA) with the following cycling conditions: initial denaturation step at $94^{\circ} \mathrm{C}$ 
Table 1 Primer sequences and band pattern analysis of eight markers in chukar partridge

\begin{tabular}{lllllll}
\hline Primer & Sequence $\left(5^{\prime}-3^{\prime}\right)$ & $\mathrm{G}+\mathrm{C} \%$ & $\begin{array}{l}\text { Total scored } \\
\text { bands }\end{array}$ & $\begin{array}{l}\text { Polymorphic } \\
\text { bands }\end{array}$ & $\begin{array}{l}\% \text { Polymorphic } \\
\text { loci }\end{array}$ & $\begin{array}{l}\text { Band size } \\
\text { range (bp) }\end{array}$ \\
\hline OP-C-08 & TGGACCGGTG & 70 & 8 & 4 & 50.00 & $300-1500$ \\
OP-C-09 & CTCACCGTCC & 70 & 11 & 5 & 45.45 & $200-1450$ \\
OP-C-20 & ACTTCGCCAC & 60 & 7 & 3 & 42.85 & $350-1250$ \\
OP-H-12 & ACGCGCATGT & 60 & 7 & 3 & 42.85 & $300-1350$ \\
PH-05 & AACGCGCAAC & 60 & 11 & 4 & 36.36 & $250-1500$ \\
PH-04 & AAGAGCCCGT & 60 & 7 & 3 & 42.85 & $350-1200$ \\
PH-03 & GTAGACCCGT & 60 & 5 & 2 & 40.00 & $300-1200$ \\
OP-C-15 & GACGGATCAG & 60 & 11 & 4 & 36.36 & $250-1400$ \\
\hline
\end{tabular}

for $3 \mathrm{~min}$; 45 cycles of $94^{\circ} \mathrm{C}$ for $30 \mathrm{~s}, 36^{\circ} \mathrm{C}$ for $1 \mathrm{~min}$, and $72^{\circ} \mathrm{C}$ for $1 \mathrm{~min}$; and a final extension step at $72^{\circ} \mathrm{C}$ for $5 \mathrm{~min}$. The PCR amplifications were duplicated for each locus at different times to decrease the risk of obtaining different RAPD bands for the same individuals, which has been reported by some researchers as a defect of the random amplified polymorphic DNA-polymerase chain reaction (RAPD-PCR) technique (Ellsworth et al. 1993). PCR products were run on a $2 \%$ agarose gel containing ethidium bromide at $70 \mathrm{~V}$ for $2 \mathrm{~h}$, along with a Gene-Ruler DNA ladder mix as the molecular weight marker (Fermentas), and visualized using a UVdoc gel documentation system. Band patterns were detected visually on agarose gel and analyzed using Popgen32 software, version 1.31 (Yeh and Boyle 1997).

\section{Results and Discussion}

All random primers showed clear and polymorphic bands in all samples (Fig. 2). To score the band pattern, we assumed that one band corresponded to one locus. After the duplication tests, it was concluded that the RAPD bands acquired in this study are reproducible. The number of polymorphic bands varied from 2 to 5 , with a range of 200-1500 bp (Table 1). Primers of OP-C-09 and PH-03 showed the highest and lowest number of polymorphic bands, respectively. Primer OP-C-08 showed the highest percentage of polymorphic loci $(50 \%)$, and primers $\mathrm{PH}-05$ and OP-C-15 had the lowest $(36.36 \%)$.

Statistical analysis of genetic variation for all loci revealed maximum gene diversity for OP08-1 and minimum gene diversity for PH05-2, with a mean of $0.4405 \pm 0.0755$ (Table 2). The 67 loci amplified produced 28 polymorphic bands (42\%) among all investigated populations. All primers used in this study were highly informative, producing an average of eight bands per primer. The percentage of polymorphic loci in these populations ranged from 36 to $50 \%$. Our results indicate that the majority of genetic diversity $(50 \%)$ is within populations.

To study the genetic relationships between populations, we constructed a dendrogram (Fig. 3) using Nei's (1972, 1978) genetic identity and the genetic distance data (Table 3). The Kalat-e-Nader and Mashhad populations appear to be 


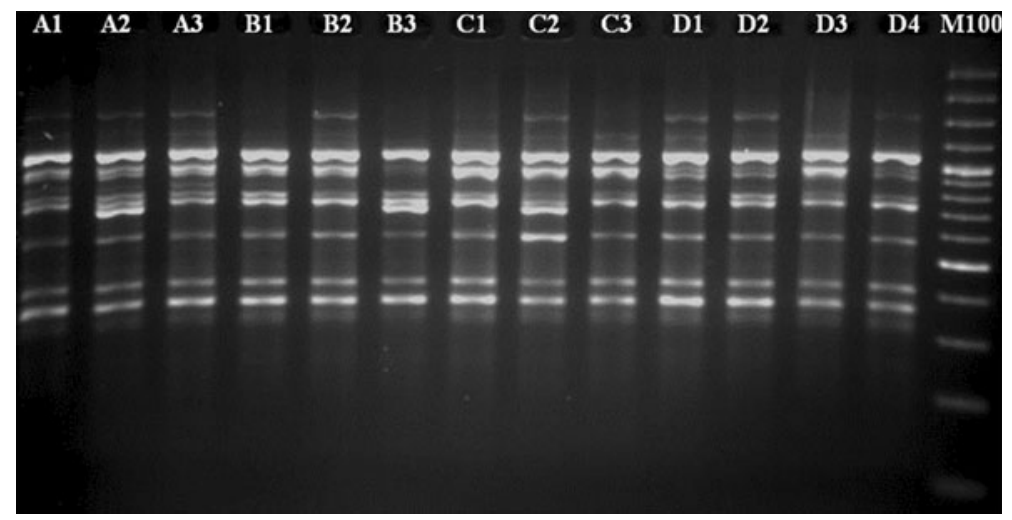

Fig. 2 RAPD banding pattern of marker OP-H-12. Lanes A1-3 samples from Kalat-e-Nader, lanes B1-3 samples from Mashhad, lanes C1-3 samples from Torbat-e-Jaam, lanes D1-4 samples from Quchan, lanes M100 100 bp ladder

the most closely related, probably because of migration and introgression between these populations. Furthermore, Kalat-e-Nader has the same climate as Mashhad, and Quchan and Torbat-e-Jaam have similar climates. Climate change affects animal genetic diversity (Hoffmann 2010). Although many existing technologies in animal genetic resource characterization, conservation, and breeding will be crucial for climate change adaptation and mitigation, research gaps do exist, especially with regard to the physiology and genetics of adaptation (Hoffmann 2010). Our results indicate that the mean genetic diversity among the populations studied is sufficient $(0.4405 \pm 0.0755)$, and there is probably enough gene flow between populations. So, the results show that genetic diversity in these populations is acceptable (Xiao et al. 2004).

Selected RAPD markers can be highly effective in disclosing hybridization and genetic diversity of a given specimen (Negro et al. 2001; Barbanera et al. 2005). A considerable number of primers, however, are required to demonstrate genetic purity, or the absence of any introgressive event (Boecklen and Howard 1997). In this study, the use of eight primers together offered complementary information for their detection, and the set of eight markers met the condition that they were present in all Alectoris chukar tested.

The results demonstrate that optimized RAPD methodology can be used to obtain genetic band patterns that are reproducible in partridges and is an effective way to detect hybrids. This information can be complemented with other markers, such as SSCPs and SNPs, to increase the reliability of detecting hybrids (Garcia and Arruga 2006).

The majority of RAPD bands are common for most populations. Some RAPD loci were not found in particular populations. No population-specific loci were obtained. The results demonstrate the usefulness of the RAPD approach for detecting DNA polymorphism and establishing relationships among populations of partridge. 
Table 2 Genetic variation for all loci ${ }^{\mathrm{a}}$

\begin{tabular}{|c|c|c|c|c|c|}
\hline \multirow[t]{2}{*}{ Locus } & \multirow{2}{*}{$\begin{array}{l}\text { Sample } \\
\text { size }\end{array}$} & \multicolumn{2}{|c|}{ Number of alleles } & \multirow{2}{*}{$\begin{array}{l}\text { Nei's gene } \\
\text { diversity }\end{array}$} & \multirow{2}{*}{$\begin{array}{l}\text { Shannon's } \\
\text { information index }\end{array}$} \\
\hline & & Observed & Effective $^{b}$ & & \\
\hline OP08-1 & 75 & 2.0000 & 1.9999 & 0.5000 & 0.6931 \\
\hline OP08-2 & 75 & 2.0000 & 1.9941 & 0.4985 & 0.6917 \\
\hline OP08-3 & 75 & 2.0000 & 1.9273 & 0.4811 & 0.6742 \\
\hline OP08-4 & 75 & 2.0000 & 1.9975 & 0.4994 & 0.6925 \\
\hline OP09-1 & 75 & 2.0000 & 1.5720 & 0.3639 & 0.5501 \\
\hline OP09-2 & 75 & 2.0000 & 1.8427 & 0.4573 & 0.6498 \\
\hline OP09-3 & 75 & 2.0000 & 1.9724 & 0.4930 & 0.6231 \\
\hline OP09-4 & 75 & 2.0000 & 1.9723 & 0.4930 & 0.6861 \\
\hline OP09-5 & 75 & 2.0000 & 1.8632 & 0.4930 & 0.6426 \\
\hline OP20-1 & 75 & 2.0000 & 1.9968 & 0.4992 & 0.6923 \\
\hline OP20-2 & 75 & 2.0000 & 1.8813 & 0.4685 & 0.6613 \\
\hline OP20-3 & 75 & 2.0000 & 1.7161 & 0.4173 & 0.6080 \\
\hline OP12-1 & 75 & 2.0000 & 1.7632 & 0.4329 & 0.6244 \\
\hline OP12-2 & 75 & 2.0000 & 1.9941 & 0.4985 & 0.6917 \\
\hline OP12-3 & 75 & 2.0000 & 1.9991 & 0.4998 & 0.6929 \\
\hline PH05-1 & 75 & 2.0000 & 1.7130 & 0.4162 & 0.6069 \\
\hline PH05-2 & 75 & 2.0000 & 1.3684 & 0.2692 & 0.4402 \\
\hline PH05-3 & 75 & 2.0000 & 1.5816 & 0.3677 & 0.5543 \\
\hline PH05-4 & 75 & 2.0000 & 1.8716 & 0.4687 & 0.6641 \\
\hline PH04-1 & 75 & 2.0000 & 1.8360 & 0.4553 & 0.6478 \\
\hline PH04-2 & 75 & 2.0000 & 1.7412 & 0.4911 & 0.5261 \\
\hline PH04-3 & 75 & 2.0000 & 1.8710 & 0.4635 & 0.6519 \\
\hline PH03-1 & 75 & 2.0000 & 1.8322 & 0.4542 & 0.6466 \\
\hline PH03-2 & 75 & 2.0000 & 1.7514 & 0.4290 & 0.6204 \\
\hline PH15-1 & 75 & 2.0000 & 1.2884 & 0.2239 & 0.3834 \\
\hline OP15-2 & 75 & 2.0000 & 1.6258 & 0.3849 & 0.5732 \\
\hline OP15-3 & 75 & 2.0000 & 1.6242 & 0.3843 & 0.5725 \\
\hline OP15-4 & 75 & 2.0000 & 1.7524 & 0.4325 & 0.6571 \\
\hline Mean & 75 & 2.0000 & 0.6220 & 0.4405 & 1.7954 \\
\hline SD & & 0.0000 & 0.0831 & 0.0755 & 0.2084 \\
\hline
\end{tabular}

\footnotetext{
a Nei (1987)

b Kimura and Crow (1964)

c Nei (1973)

d Lewontin (1972)
}

The selection of animals with the least genetic similarity can help to conserve the maximum variability within a population and can even optimize the choice of breeders for ex situ conservation programs. 


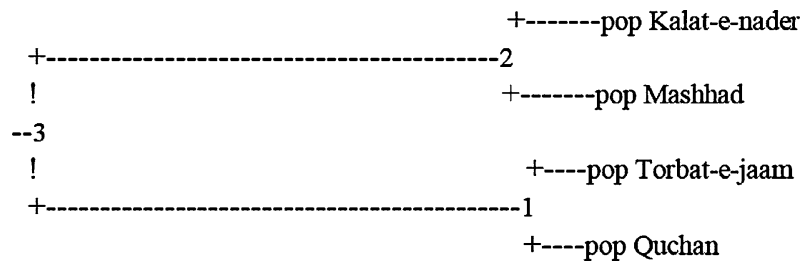

Fig. 3 Dendrogram constructed using Nei's coefficient of similarity between populations

Table 3 Genetic identity of four chukar populations

\begin{tabular}{lllll}
\hline Population & Kalat-e-nader & Mashhad & Torbat-e-jaam & Quchan \\
\hline Kalat-e-nader & - & 0.9842 & 0.9299 & 0.8615 \\
Mashhad & 0.0159 & - & 0.9401 & 0.8787 \\
Torbat-e-jaam & 0.0727 & 0.0617 & - & 0.9892 \\
Quchan & 0.1491 & 0.1293 & 0.0108 & - \\
\hline
\end{tabular}

Nei's genetic identity (above diagonal) and genetic distance (below diagonal)

Acknowledgments The authors extend special thanks to the excellent Centre in Animal Science of Ferdowsi University of Mashhad, Iran, and the Environment Protection Organization of Khorasan-eRazavi, Iran, for providing necessary facilities, equipments and partridge blood samples. This work was supported by a grant of the agricultural faculty of Ferdowsi University of Mashhad, Iran.

\section{References}

Barbanera F, Negro JJ, Di Giuseppe G, Bertoncini F, Cappelli F, Dini F (2005) Analysis of the genetic structure of red-legged partridge (Alectoris rufa, Galliformes) populations by means of mitochondrial DNA and RAPD markers: a study from central Italy. Biol Conserv 122:275-287

Boecklen WJ, Howard DJ (1997) Genetic analysis of hybrid zones: numbers of markers and power of resolution. Ecology 78:2611-2616

Boom R, Sol CJA, Salimans MMM, Jansen CL, Wertheimvandillen PME, Vandernoordaa J (1990) Rapid and simple method for purification of nucleic acids. J Clin Microbiol 28:495-503

D'Amato ME, Corach D (1996) Genetic diversity of populations of the freshwater shrimp Macrobrachium borelli (Caridae: Palaemonidae). J Crust Biol 16(4):650-655

Diaz V, Muniz LM, Ferrer E (2001) Random amplified polymorphic DNA and amplified fragment length polymorphism assessment of genetic variation in Nicaraguan populations of Pinus oocarpa. Mol Ecol 10:2593-2603

Egito AA, Fuck B, Spritze AL, Oliveira RR, McManus C, Mariante AS, Ribeiro MN, Albuquerque MSM, Paiva SR, Castro STR, Santos SA (2005) RAPD markers utilization on the formation or maintenance of conservation nuclei of livestock species. Arch Zootec 54:277-281

Ellsworth DL, Rittenhouse KD, Honeycutt RL (1993) Artifactual variation in randomly amplified polymorphic DNA banding patterns. BioTechniques 14:214-217

Excoffier L, Smouse PE, Quattro JM (1992) Analysis of molecular variance inferred from metric distances among DNA haplotypes: application to human mitochondrial DNA restriction data. Genetics 131:479-491

Frankham R (2005) Genetics and extinction. Biol Conserv 126:131-140

Garcia CB, Arruga MV (2006) Application of RAPD methodology to preserve the purity of wild redlegged partridges (Alectoris rufa, L.). Wildl Biol Pract 2(1):13-16

Hadrys H, Balick M, Schierwater B (1992) Applications of random amplified polymorphic DNA (RAPD) in molecular ecology. Mol Ecol 1:55-63 
Hetzel DJS, Drinkwater RD (1992) The use of DNA technologies for the conservation and improvement of animal genetic resources. In: Hodges J (ed) The management of global animal genetic resources. Proceedings of an FAO expert consultation, Rome, Italy, 309 pp

Hoffmann I (2010) Climate change and the characterization, breeding and conservation of animal genetic resources. Anim Genet 41(1):32-46

Huff DR, Peakall R, Smouse PE (1993) RAPD variation within and among natural populations of outcrossing populations of outcrossing buffalograss (Buchloe dactyoides (Nutt.) Engelm.). Theor Appl Genet 86:927-934

Kimura M, Crow JF (1964) The number of alleles that can be maintained in a finite population. Genetics 49:725-738

Lewontin RC (1972) The apportionment of human diversity. Evol Biol 6:381-398

Lynch M, Milligan BG (1994) Analysis of population genetic structure with RAPD markers. Mol Ecol 3(2):91-99

Madge S, McGowan P (2002) Pheasants, partridges and grouse: a guide to the pheasants, partridges, quails, grouse, guineafowl, buttonquails and sandgrouse of the world. Christopher Helm, London

McFarland DC (1991) The biology of the ground parrot, Pezoporus wallicus, in Queensland. III. Distribution and abundance. Wildl Res 18(2):199-213

Negro JJ, Torres MJ, Godoy JA (2001) RAPD analysis for detection and eradication of hybrid partridges (Alectoris rufa $\times$ A. graeca) in Spain. Biol Conserv 98(1):19-24

Nei M (1972) Genetic distance between populations. Am Nat 106:283-292

Nei M (1973) Analysis of gene diversity in subdivided populations. Proc Natl Acad Sci USA 70:3321-3323

Nei M (1978) Estimation of average heterozygosity and genetic distance from a small number of individuals. Genetics 89:583-590

Nei M (1987) Molecular evolutionary genetics. Columbia University Press, New York

Nybom H (2004) Comparison of different nuclear DNA markers for estimating intraspecific genetic diversity in plants. Mol Ecol 13:1143-1155

Volis S, Yakubov B, Shulgina I, Ward D, Zur V, Mendlinger S (2001) Tests for adaptive RAPD variation in population genetic structure of wild barley, Hordeum spontaneum Koch. Biol J Linn Soc 74:289-303

Welsh J, McClelland M (1990) Fingerprinting genome-using PCR with arbitrary primers. Nucleic Acids Res 18:7213-7218

Williams JGK, Kubelik AR, Livak KJ, Rafalski JA, Tingey SV (1990) DNA polymorphism amplified by arbitrary primers are useful as genetic markers. Nucl Acids Res 18:6531-6535

Xiao Y, Shuang J, Kangyun D, Xiao Z, Zhihua C, Jincheng Z (2004) Study on genetic variation in yak breeds (populations) by RAPD. In: Proceedings of the International Congress on Yak, Chengdu, Sichuan, China

Yeh FC, Boyle TJB (1997) Population genetic analysis of co-dominant and dominant markers and quantitative traits. Belg J Bot 129:157 